\title{
RISK MANAGEMENT AND LIABILITY FOR ENVIRONMENTAL HARM CAUSED BY GMOS - THE SOUTH AFRICAN REGULATORY FRAMEWORK
}

\section{FERIS*}

\section{Introduction}

South Africa has an active Genetically Modified Organism (GMO) industry and it has been stated that South Africa's uptake of GMOs is one of the fastest in the world. ${ }^{1}$ In 1999 approximately 250000 hectares of farmland was planted with GM crops. This figure has increased by 100000 hectare per year. ${ }^{2}$ South Africa is thus fast becoming one of the leading countries in the uptake of genetically modified organisms. This technology is still relatively new and as with any new technology, it carries some level of risk. Given that the potential impacts of biotechnology are not yet fully understood, it is quite likely that in the production, development or release of a GMO it may cause injury to person, property or the environment. This necessitates the existence of a liability regime that will place some legal responsibility on the party responsible for the harm.

Legal liability regimes are now fairly common in the environmental law arena and lately it has begun to specifically include liability for damage to the environment caused by GMOs. ${ }^{3}$ This paper examines the South African legal

* Associate Professor of Law, University of Pretoria.

1 Biowatch http://www.biowatch.org.za/docs/booklets/gebk4.pdf 15 Jun.

2 Id. The acceptance of Bt cotton by small-scale farmers in KwaZulu-Natal is illustrative of this point. In 1997 only four farmers cultivated Bt cotton. In 1998 this increased to 75, with 200 hectares under cultivation. By the year 2000 the number totalled 644, with 1250 hectares being planted, which accounts for approximately $50 \%$ of the total area of planted cotton in that region. Thompson Genes for Africa 32.

3 See eg a 14 EC Directive on Environmental Liability with Regard to the Prevention and Remedying of Environmental Damage of the European Parliament and Counsel adopted 
system to assess the way it deals with risk management and legal liability for GMO related harm to the environment and determine whether it addresses these issues in an effective and adequate manner.

\section{Liability and risk management in the context of GMOs}

GMOs are able to interact with other forms of life, reproduce, transfer their characteristics and mutate in response to environmental influences. As a result, they can impact on the environment and more particularly on biodiversity. For example, they may

...place existing plants and animals, disrupt the functioning of ecosystems, reduce biological diversity, alter the composition of species, and even threaten the extinction of various species and change climate patterns. ${ }^{4}$

There is also the additional risk of harming traditional knowledge systems reliant on indigenous biological resources. Liability regimes attempt to provide a remedy in those instances where injury or damage actually occurs.

The Cartagena Protocol on Biosafety to the Convention on Biodiversity ${ }^{5}$ (hereafter "the Protocol") plays an important role in this regard. The Protocol regulates the

...transboundary movement, transit, handling and use of living modified organisms (LMOs) ${ }^{6}$ that may have adverse effects on the conservation and sustainable use of biological diversity, taking also into account risks to human health. ${ }^{7}$

on 21 April 2004 which aims to prevent and remedy environmental damage that presents a threat to human health.

$4 \quad$ Repp 2000 Idaho LR 585-591 quoting Mellon Biotechnology and the Environment 8.

5 2000. Cartagena Protocol http://www.biodiv.org/biosafe/protocol.asp 15 Jun, signed June 2003, acceded August 2003.

6 The term "living modified organism" is defined as any living organism with a novel combination of genetic material obtained through biotechnology. A 3(g) Cartagena Protocol http://www.biodiv.org/biosafe/protocol.asp 15 Jun.

7 Id a 4. Except those used as human pharmaceuticals and addressed by other relevant international agreements, those in transit, and those destined for contained use. 
It establishes two procedures for transboundary movements of LMOs. The socalled Advanced Informed Agreement (AIA), which requires advanced notification of the introduction of LMOs into a country of import. The Party of export must notify the Party of import about the transboundary movement of LMOs. The latter has the option of approving, prohibiting or conditionally approving the import. The AIA only applies to the

...first intentional transboundary movement of LMOs for the intentional introduction into the environment of the Part of import. ${ }^{8}$

This would apply to the environmental release of plants and seeds for example. Any plants or animal product destined for food, animal feed or processing are explicitly excluded. ${ }^{9}$ A separate procedure applies to a Party's final decision regarding domestic use, including placing on the market of LMOs that may be subject to transboundary movement for direct use as food or feed, or for processing. When a Party makes a final decision regarding the domestic use of such an LMO, it has the obligation to inform the other parties of that decision within fifteen days through the Biosafety Clearing-House of the Protocol.

The Protocol furthermore provides for liability for damage that may arise due to the transboundary movement of GMOs. Article 27 of the Protocol states that:

The Conference of the Parties serving as the meeting of the Parties to this Protocol shall, at its first meeting, adopt a process with respect to the appropriate elaboration of international rules and procedures in the field of liability and redress for damage resulting from transboundary movements of living modified organisms, analyzing and taking due account of the ongoing processes in international law on these matters, and shall endeavour to complete this process within four years.

A detailed liability regime is currently under negotiation. ${ }^{10}$

$8 \quad$ Id a 7.1.

9 Id a 7.2.

10 Decision BS-I/8 dated February 2004 to establish an Open-ended Ad Hoc Working Group of Legal and Technical Experts on Liability and Redress. 
The Protocol essentially implements the "polluter pays" principle which aims to hold polluters responsible for environmental damage and any subsequent remediation of the environment. It can be argued that a liability regime, because of the financial responsibility that it encompasses, creates observance not only to the above principle, but additional environmental principles such as the "precautionary approach", "preventive principle" and "duty of care principle". A liability regime simultaneously promotes compliance with environmental regulatory measures and ensures that redress is provided where unlawful actions cause injury to the environment or third parties.

A further criterion that pervades regulatory frameworks for GMOs is the requirement that the introduction of this type of technology proceeds through risk assessment and risk management principles. Since risk can liberally be defined in terms of chance or uncertainty, it is clear that risk assessment and risk management are not designed to assure a total absence of harm. Rather, vis-a-vis GMOs, risk assessment and risk management are designed to optimize the benefit of environmental introductions of such products while simultaneously minimizing any detrimental consequences. ${ }^{11}$

The Biosafety Protocol provides for risk assessments, which has to be undertaken in a "scientifically sound manner"12 and according to international guidelines. ${ }^{13}$ At present, the Protocol represents the minimum standard for Biosafety and GMO regulation and does not deal comprehensively with risk assessment and risk management.

Risk assessment, which is essentially a scientific process, endeavours to identify and estimate the likelihood of an adverse outcome resulting from an activity or a product. ${ }^{14}$ Key to calculating the likelihood of such an adverse

11 Szecsy A 1997 Dick J Envtl L \& Pol'y 177-192.

12 Id a 10.

13 Annex III sets out the conditions for risk assessment. Pursuant to a 6 the notifier bears the cost of the risk assessment.

14 Guruswamy 2002 Ind J of Global Legal Stud 461-479. 
outcome is the identification of potential risks. One of the well-known tools for risk identification is environmental impact assessments (EIAs), which identifies the impacts of human activities on the environment, human health and wellbeing. ${ }^{15}$ EIAs are a generally accepted international environmental norm of procedure, because it is considered important for environmental, economic, social, cultural, and health concerns to be accounted for early in any development project. ${ }^{16} \mathrm{An}$ EIA is in essence an assessment of the potential environmental risks before a project is commenced. It allows problems to be mitigated before they occur, and other cost-effective strategies to be devised to avert the damage proposed by the original development plan. ${ }^{17}$ In this respect, the Convention on Environmental Impact Assessment ${ }^{18}$ requires that

...[t]he Parties shall, either individually or jointly, take all appropriate and effective measures to prevent, reduce and control significant adverse transboundary environmental impact from proposed activities. $^{19}$

Risk management is a broader mechanism in which the scientific findings of risk assessment becomes part of the broader structure of policy and law and where decisions are made on how the risk can be controlled, monitored and regulated. ${ }^{20}$ Whilst risk assessment is essentially a scientific process, risk management goes much further and has been defined as

...the systematic application of management policies, procedures and practices to the tasks of analyzing, evaluating, controlling and communicating about risk issues. ${ }^{21}$

Key elements of the risk management process include: identifying every potential source of harm (hazard); assessing the probability of occurrence of

15 Ross and Thompson Environmental Impact Assessment 231.

16 Graziano 1996 CJIELP 179-202.

17 Id.

18 Espoo Convention - Convention on Environmental Impact Assessment 25 February 1991, in force 10 September 1997.

19 A 2(1).

20 Guruswamy 2002 Ind J of Global Legal Stud 480.

21 Canadian Standards Association Risk Management: Guidelines for Decision Makers Q850-97 quoted in Kirkland et al Risk Management 156- 158. 
that harm (exposure); assessing the risk, if any, resulting from the potential combination of hazard and exposure; and the development of alternatives for the minimisation and management of the assessed risks. ${ }^{22}$ Risk management can therefore be divided into six components; that is:

- Risk identification

- Risk assessment

- Risk control and mitigation

- Emergency response

- Risk communication

- Risk perception

I would contend that a seventh component would be legal responsibility for risk, a component that flows from liability for damage to the environment, property or persons. It has been argued:

...[f]or products of agricultural biotechnology, the potential risks and risk management alternatives must be evaluated in the context of such factors as health, safety, environmental, and agricultural impacts; regulatory acceptance; public acceptance; market acceptance; and civil liability (emphasis added). ${ }^{23}$

An effective risk management regime should thus incorporate risk assessment that would in turn have the effect of lowering liability for damage flowing from the activity. A regulatory framework for GMOs should ideally provide for this inter-action between risk management and liability.

\section{$3 \quad$ The existing South African regulatory framework}

The South African regulatory framework of relevance to GMOs is composed of a fragmented set of laws that deals with risk assessment, risk management and

22 Abramson and Carrato 2001 Va Env'l L J 241-261.

23 Id. 
liability for damage to the environment. These laws, which largely fail to prescribe an effective overarching risk assessment and liability regime for GMOs, include the: National Environmental Management Act (NEMA); ${ }^{24}$ Environment Conservation Act; ${ }^{25}$ Genetically Modified Organisms Act (GMO Act) $;{ }^{26}$ and the National Environmental Management: Biodiversity Act. $^{27}$ The current regulatory framework is construed in the context of the Constitution of the Republic of South Africa (the Constitution) ${ }^{28}$ and in particular in the context of section 24 which states:

Everyone has the right -

(a) to an environment that is not harmful to their health or wellbeing; and

(b) to have the environment protected, for the benefit of present and future generations, through reasonable legislative and other measures that -

(i) prevent pollution and ecological degradation

(ii) promote conservation; and

(iii) secure ecologically sustainable development and use of natural resources while promoting justifiable economic and social development.

Section 24 attempts to fulfil two general aims. Subsection (a) guarantees a healthy environment to everyone in general while subsection (b) mandates the state to take certain measures to realise the guarantee proclaimed in subsection (a). Implicit in subsection (b) is a positive duty on the state to protect the environment through tools such as risk management and liability regimes. Subsection (b) also affords protection against any state action that negates environmental protection or that it is any way harmful to the environment.

24 Act 107 of 1998.

25 Act 73 of 1989.

26 Act 15 of 1997. See also Draft Biosafety Policy (GN 1576 GG 27913 dated 26 August 2005); Draft Discussion Document on Agricultural Biotechnology (GN 1591 GG 27936 dated 26 August 2005); Guideline Document for Use by the Advisory Committee when Considering Proposals/Applications for Activities with Genetically Modified Organisms (GN 1047 GG 26422 dated 11 June 2004).

27 Act 10 of 2004. Other legislation of relevance to the management of GMOs include: the Agricultural Pests Act 36 of 1983; the Foodstuffs, Cosmetics and Disinfectants Act 52 of 1972; and the Fertilisers, Farm Feeds, Agricultural and Stock Remedies Act 36 of 1947.

28 Constitution of the Republic of South Africa, 1996. 


\section{The Genetically Modified Organisms Act}

GMOs are principally regulated by the GMO Act, which

...provide for measures to promote the responsible development, production, use and application of genetically modified organisms,

and

...ensure that all activities involving the use of genetically modified organisms (including importation, production, release and distribution) shall be carried out in such a way as to limit possible harmful consequences to the environment. ${ }^{29}$

A Genetically Modified Organisms Amendment Bill (Amendment Bill amend certain provisions of the GMO Act, largely to ensure compliance with South Africa's commitments in terms of the Cartagena Protocol. ${ }^{30}$

The GMO Act currently applies to: ${ }^{31}$

- the genetic modification of organisms;32

- the development, production, release, use and application of GMOs (including viruses and bacteriophages); and

- the use of gene therapy. ${ }^{33}$

Section 5(a) of the GMO Act provides that the Executive Council of Genetically Modified Organisms (hereafter Council), the primary regulatory authority, may require an applicant who applies for a permit to use facilities for the development, production, use or application of GMOs or to release GMOs into the environment to conduct a risk assessment or an environmental impact

29 The Preamble of the Act.

30 Genetically Modified Organisms Amendment Bill R 2166 of 8 October 2004.

31 S 2(1)(a)-(c).

32 A genetically modified organism is defined as "an organism the genes or genetic material of which has been modified in a way that does not occur naturally through mating or natural recombination or both..." $\mathrm{s} 1$ (xiii).

33 S 1 (xii) defines gene therapy as "a technique for delivering functional genes (to replace aberrant ones) into living cells by means of a genetically modified vector or by physical means in order to genetically alter the cell". 
assessment. $^{34}$ This raises two issues for consideration: First, the provision specifically excludes the import of GMOs from the ambit of risk assessments. This is not a very satisfying approach, as it cannot be safely assumed that a GMO that has been approved outside of South Africa can be safely released into the South African environment. Section 4 of the Amendment Bill attempts to remedy this shortcoming and extends the ambit of section 5(a) to "activities in relation to genetically modified organisms" where "activity" is defined to include import and export. ${ }^{35}$ However, the risk assessment provisions under the regulations issued in terms of the Act define "activity" as

...work undertaken with regard to the development, production, use and application of genetically modified organisms.

This latter definition will need to be amended in the future to bring it in line with the Amendment Bill.

Second, section 5 is clearly not a peremptory provision and the use of the word "may" suggest that the Council has some discretion in this regard. This has the implication that the GMO Act does not provide for mandatory EIAs or risk assessments. The Amendment Bill retains this discretion ${ }^{36}$ and where an environmental impact assessment has been conducted, the Council has a further discretion to decide whether to consider such assessment in granting the permit. ${ }^{37}$ The regulations issued in terms of the GMO Act, on the other hand, states that

...no person shall undertake any activity involving genetically modification, unless a suitable and sufficient assessment of risks created thereby to the environment and human health has been made. $^{38}$

36 S $5(1)(a)$ provides: "the Council shall (a) where an applicant applies ....for a permit to conduct activities in respect of genetically modified organisms determine whether that applicant must, in addition to his or her submission, submit an assessment of the impact on the environment and socio-economic considerations of the activity".

$37 \quad \mathrm{~S} 5(2)$.

38 Reg 3(1) in R1420 in GG 20463 dated 26 November 1999. 
The regulations seem to suggest that a risk assessment is a requirement for the prescribed activities related to GMOs. However, the obligation to conduct a risk assessment exists only where the activity involves the development, use, production and application of GMOs and not where the activity involves the release of GMOs into the environment. ${ }^{39}$

It must be noted, however, that section 17 of the Act places a duty of care on all users of GMOs. In terms of this duty, users should take all appropriate measures to avoid an adverse impact on the environment resulting from the use of GMOs. It is not clear what such measures may be, but one can certainly make the argument that these measures should include a risk assessment. It is worth noting that since the promulgation of the GMO Act no applicant has been required to undertake a full EIA under the Act.

In addition to the lack of clarity around mandatory risk assessment, the Act also lacks clarity on the criteria in terms of which such a risk assessment (whether mandatory or not) should be completed and what procedure should be followed. Neither the regulations nor the Amendment Bill attempts to resolve this matter. ${ }^{40}$ The Department of Agriculture has issued a Guideline Document for Work with Genetically Modified Organisms. ${ }^{41}$ These Guidelines provide information on risk assessment and risk management but do not, however, create any legally binding obligations.

Section 17 of the GMO Act addresses the issue of GMO related damage. It places the liability for damage caused by the use or release of a genetically modified organism on the user concerned. ${ }^{42}$ The only exception is when the $\mathrm{GMO}$ is in the possession of an inspector, unless the user foresaw or should

39 Barron 2003 SAJELP 93-110. The GMO Act in contrast, grants the discretion also in those instances where GMOs are released into the environment.

40 S 20 (as amended by the Amendment Bill) provides that the Minister of Agriculture may make regulations regarding the procedure to be followed for risk assessments.

41 N 26 above, GN 1046 in GG No 26422 dated 11 June 2004, 11-49.

$42 \mathrm{~S} 17(2)$. 
have foreseen such damage and could or should have prevented the damage, but failed to take reasonable action to prevent such damage. ${ }^{43}$

Liability has in the past been restricted to the "user", which is defined as

....any natural or legal person or institution responsible for the use of genetically modified organisms and includes an end-user or consumer. ${ }^{44}$

"Use" in this definition does not include the development, production, transport or application of GMOs and as such those involved in these activities are excluded from liability. This has the effect that it is only the end-user, such as farmers and consumers that are liable for damage to the environment. Section 17 has, however, been amended by the Amendment Bill which now extends liability to damage caused by "activities relating to genetically modified organisms". "Activity" is broadly defined and includes any activity with GMOs including importation, exportation, transit, development, production, release, distribution, contained use, storage and application. ${ }^{45}$ Liability is furthermore broadened to not only include the environment, but also human and animal health. ${ }^{46}$ This extension of liability is a welcome contribution in ensuring that an adequate liability regime is provided for.

The Act does not define the scope of damage is not clear therefore what type of damage is covered. Liability regimes generally distinguish three types of damage, namely: damage to the environment; damage to property; and damage to human health or life. ${ }^{47}$ Damage to the environment is often further delineated, as in the EC Directive, which defines "environmental damage" to include: "damage to protected species and natural habitats"; "water damage";

43 Id.

$44 \mathrm{~S} 1$.

$45 \mathrm{~S} 1(\mathrm{~b})$.

$46 \mathrm{~S} 17(1)$.

47 See eg the 1993 Council of Europe Convention on Civil Liability for Damage Resulting from Activities Dangerous for the Environment (Lugano Convention) 21 June 1993, not in force. 
and "land damage". ${ }^{48}$ Each of these components of environmental damage is specifically circumscribed in the definitional provision of the Directive. The absence of the delineation of the scope for liability in the GMO Act thus leaves a vacuum, which is not resolved by the Amendment Bill.

The Act fails to address a number of other issues crucial to a liability regime. First, it remains silent on the question of the standard of liability. It is thus not apparent whether liability is strict, fault-based or a combination thereof. Strict liability is the preferred standard for environmental offences and it is normally utilized in those circumstances where abnormally dangerous activities are carried out. ${ }^{49}$ Second, the GMO Act does not tackle the central issue of redress. Provisions on redress provide guidance on the duty placed on the liable party with regard to measures related to the control, containment or mitigation of the damage; clean up measures; or remediation or restoration of the damage. Finally, it makes no provision for insurance or a financial security instrument that would cover liability for environmental or other damage. It is accepted practice these days that environmental liability regimes require a financial mechanism that provides financial guarantees to cover responsibilities invoked by a liability regime. ${ }^{50}$ Several options exist which include instruments such as compulsory insurance, the provision of bonds and the establishment of a fund for clean-up costs. Such a financial mechanism is for example provided in the Mineral and Petroleum Resources Development Act ${ }^{51}$ (MPRDA) so that at the time of application for a permit to import, export, develop, produce, use or apply GMOs the operator make a prescribed financial provision for clean up costs and rehabilitation. ${ }^{52}$ NEMA similarly requires the provision of financial or

48 A 2(1)(b). Land damage is, however, limited in that it relates only to "land contamination that creates a significant risk of human health being adversely affected...".

49 See eg the 1999 Basel Protocol on Liability and Compensation to the Basel Convention on the Control of Transboundary Movements of Hazardous Wastes and their Disposal 10 December 1999, not in force.

50 See eg a 14 of the EC Directive on Environmental Liability, $\mathrm{n} 3$ above.

51 Act 28 of 2002. S 41(1).

52 In terms of Reg 52(2)(d) read with Reg 53 in GG 26275 of 23 April 2004. A financial provision may include: an approved contribution to a trust fund; a financial guarantee from a bank; a deposit into the account specified by the Director-General. 
other security to cover the risks to the State and the environment of noncompliance with conditions attached to environmental authorisations. ${ }^{53}$

\section{Framework Environmental Legislation: the Environment Conservation Act and National Environmental Management Act}

\subsection{Provision for Risk Assessment}

The Environment Conservation Act (ECA), although largely repealed, contains EIA and environmental liability provisions of relevance to GMOs. Part 5 of the ECA provides for the "Control of Environmental Activities which may have a Detrimental Effect on the Environment". This essentially requires EIAs for a number of listed activities set out in regulations. ${ }^{54}$ One of the listed activities is

...the genetic modification of any organism with the purpose of fundamentally changing the inherent characteristics of that organism. $^{55}$

Therefore, it would appear that an EIA is only triggered by the process of genetic modification rather than, for example, the proposed release, import or export thereof.

In 1998 South Africa enacted overarching environmental framework legislation in the form of the National Environmental Management Act (NEMA) ${ }^{56}$ Section 2 of NEMA contains a number of environmental management principles that include: polluter pays principle; duty of care principle; precautionary approach; public trust doctrine; and preventive principle.

With regards to risk management it requires that:

53 S 24(4)(d).

54 REG 1182 in GG 18621 dated 5 September 1997.

55 Reg 6.

56 Act 107 of 1998. 
...a risk-averse and cautious approach is applied, which takes into account the limits of current knowledge about the consequences of decisions and actions; ${ }^{57}$

...that negative impacts on the environment and on people's environmental rights be anticipated and prevented, and where they cannot be altogether prevented, are minimised and remedied; ${ }^{58}$

and that

...the social, economic and environmental impacts of activities, including disadvantages and benefits, must be considered, assessed and evaluated, and decisions must be appropriate in the light of such considerations and assessment. ${ }^{59}$

Chapter 5 of the Act provides for Integrated Environmental Management including EIA. The NEMA Amendment $\mathrm{Act}^{60}$ provides for a new environmental assessment regime in that

...the potential impact on the environment of listed activities must be considered, investigated, assessed and reported to the competent authority. ${ }^{61}$

Draft Regulations under the NEMA Amendment $\mathrm{Act}^{62}$ provide for listed geographical areas and listed activities that require EIAs.

The treatment of GMOs under the new regulations is at best confusing. The regulations contain a list of activities that require screening. ${ }^{63}$ One such listed activity is

...the release of genetically modified organisms into the environment in instances where it is required by the Genetically Modified Organisms Act or the NEMA Biodiversity Act. ${ }^{64}$

57 S 2(4)(a)(vii).

58 S 2(4)(a)(viii).

59 S 2(4)(i).

60 Act 8 of 2004

61 S 24(1).

62 GN 12 in GG 27163 dated 14 January 2005.

63 Reg 22.

64 Reg 22(22). 
There are a number of problems with this formulation.

First, it is unclear why screening is only required in those instances when it is already mandated by the GMO Act or the Biodiversity Act. Second, screening relates to the determination of the level of EIA to be applied. ${ }^{65}$ The philosophy behind screening is that in order for an EIA to be undertaken efficiently and effectively, projects with trivial impacts must be excluded from the EIA process, while other projects with possible significant impacts will require a full EIA. If the GMO Act or the Biodiversity Act requires an EIA, screening is superfluous, as it has already been decided that the release of the GMOs is likely to have a significant impact on the environment. The peculiar inclusion of GMOs into the section may be part of the misguided manner in which screening is dealt with, and specifically the fact that it includes aspects of the EIA itself into the screening process. ${ }^{66}$ Thus, the implementation of the risk adverse approach prescribed in NEMA is flawed to the extent that it does not add significantly to risk management of GMOs.

\subsection{Provision for Liability}

Liability for environmental damage is dealt with in section $31 \mathrm{~A}$ of the ECA, which directs a polluter to take steps to prevent or minimise damage to the environment. Such a polluter may also be directed to rehabilitate damage, caused to the environment.

Section 31A is a general provision on liability and like the GMO Act it does not amount to a comprehensive and detailed liability regime. It does however, provide for preventive measures to minimise damage, which could include the containment of the spread of GMOS and it specifically mandates a directive to rehabilitate the environment.

65 Ross and Thompson Tools for Environmental Management 233.

66 Glazewski Environmental Law 242. 
The cornerstone of NEMA in terms of liability is the "polluter pays" principle, which is concretised in section 28 that establishes a duty of care and provides for liability where this duty is breached. ${ }^{67}$ In addition, section 30 provides for liability for the consequences of emergency incidences of a serious nature. Section 28 provides that:

Every person who causes, has caused or may cause significant pollution or degradation of the environment must take reasonable measures to prevent such pollution or degradation from occurring, continuing or recurring, or, in so far as such harm to the environment is authorised by law or cannot reasonably be avoided or stopped, to minimise and rectify such pollution or degradation of the environment. $^{68}$

Section 28(4) furthermore provides that the Director-General or a provincial head of department may direct any person who fails to take the measures required to:

a. investigate, evaluate and assess the impact of specific activities and report thereon;

b. commence taking specific reasonable measures before a given date;

c. diligently continue with those measures; and

d. complete them before a specified reasonable date.

Section 28 casts a wide net and any damage caused by GMOs to the environment could potentially fall under this section. "Degradation" is characterised as "general reduction in the quality of the environment". ${ }^{69}$ The concept "environment" is widely defined in NEMA and consists of the: ${ }^{70}$

...surroundings within which humans exist and that are made up of

i. the land, water and atmosphere of the earth;

ii. microorganisms, plant and animal life;

67 Soltau F "The National Environmental Management Act and Liability for Environmental Damage" 61999 SAJELP 33-41.

68 S 28(1).

69 Soltau 1999 SAJELP 44.

$70 \mathrm{~S} 1(\mathrm{xi})$. 
iii. any part or combination of (i) and (ii) and the interrelationships among and between them; and

iv. the physical, chemical, aesthetic and cultural properties and conditions of the foregoing that influence human health and wellbeing.

Degradation could thus include harm to ecosystems and more broadly to biodiversity, especially where the introduction of GMOs leads to contamination and the extinction of indigenous species. "Pollution" is defined as

....any change in the environment caused by substances..., where that change has an adverse effect on human health or well-being or on the composition, resilience and productivity of natural and managed ecosystems..., or will have such an effect in future. ${ }^{71}$

GMOs could fall under the scope of "substances"72 and accordingly within the definition of "pollution".

Both the concepts "degradation" and "pollution" are qualified and section 28 only applies to significant degradation or pollution. This could easily become an escape mechanism for would be defendants. However, in Hichange Investments $v$ Cape Produce Company ${ }^{73}$ the court assessed "significant pollution" in the context of the emission of chemical waste products by the respondent's tannery and stated that

...the assessment of what is significant involves, in my view, a considerable measure of subjective import ... [and]...that the threshold level of significance will not be particularly high.

Commentators have recognised the fact that section 28 works retrospectively as it includes the phrase "has caused". ${ }^{74}$ This would have the effect that any person who has caused environmental damage in the past is obliged to ensure that preventive measures are taken to avoid further degradation or to prevent

71 S 1 (xxiv).

72 Webster's College Dictionary describes "substance" as physical matter or material.

73 Hichange Investments v Cape Produce Company 2004 (2) SA 393 ECD at 414I-415A.

74 Glazweski Environmental Law 150. 
degradation from recurring. Such a person would also have the duty to minimise and rectify the environmental harm. In a recent High Court decision, Chief Pule Shadrack VII Bareki v Gencor Limited ${ }^{75}$ the court held, however, that section 28 does not work retrospectively. The court relies on the common law rule against retrospectivity and states that fairness dictates that individuals should have an opportunity to know what the law is and to act accordingly. ${ }^{76}$ It furthermore stated that the words 'has caused' were simply intended to refer to

...a person who at some stage after the commencement of NEMA has caused pollution, but is no longer doing so.

This is an unfortunate ruling as it brings into question the value of the "polluter pays" principle. Vast and extensive damage has been caused to the environment prior to the enactment of NEMA and this ruling may mean that many a polluter can simply walk away from any environmental degradation they have caused prior to NEMA's enactment. This may arguably be an infringement of section 24 of the Bill of Rights.

Liability in section 28 is channelled towards "every person", which is a wide concept. It is, however, furthermore elaborated on to include: "an owner of land or premises"; "a person in control of land or premises"; and

...a person who has the right to use the land or premises on which or in which:

a. any activity is or was performed or undertaken; or

b. any other situation exists,

c. which causes, has caused or is likely to cause significant pollution or degradation of the environment. ${ }^{77}$

75 Chief Pule Shadrack VII Bareki v Gencor Limited (TPD) Case Number 19895/2003 (unreported, copy on file with the author). The court distinguishes between retroactivity and retrospectivity and states that a retroactive act is one that operates as of a time prior to its enactment, while a retrospective statute is prospective, but imposes new results in respect of a past event.

76 Id $\mathrm{p} 20$.

77 S 28(2). 
Any farmer, including one that does not own the land would therefore be liable. While section 28(2) refers to the specific category of those who own or are in control in land, it explicitly leaves the scope open to include other categories of defendants. ${ }^{78}$ In practice, liability for damage caused by the release of GMOs would revert to the farmer, as it is not easy to contemplate the liability of the developer or producers of GMOs under this provision.

Subsection 7 provides that the Director General or provincial head of government may take reasonable measures to remedy the situation where a person fails to comply or comply inadequately. Any clean-up costs may then be recovered from those responsible for the damage. The section furthermore stipulates what action should be taken and set out a range of measures, which include containing or preventing the movement of pollution or the causant of degradation $^{79}$ and remedying the effects of pollution and degradation. ${ }^{80}$

The question is whether actors are held strictly liable. Subsection 1 indicates that anyone who causes pollution or degradation of the environment must take reasonable measures to prevent the harm from occurring, continuing or recurring. It has been argued that is not an absolute duty and is qualified by the notion of reasonableness. ${ }^{81}$ Thus, actors are not expected to prevent or remedy the effects of pollution or degradation at all costs. It has also been suggested that courts would apply the common law negligence test to establish reasonableness, namely whether harm was foreseeable and whether the defendant took the necessary steps to avoid it. ${ }^{82}$ Thus, if somebody leases farmland on which GM crops are planted, the question would be whether that person had known that the crops were genetically modified and whether he or she had taken the measures to guard against environmental damage.

78 S 28(2) states: "Without limiting the generality of the duty in subsection (1)..." S 1 refers to any person.

79 S 28(3)(d).

80 S 28(3)(f).

81 Soltau 1999 SAJELP 45.

$82 \mathrm{ld}$. 
I disagree. In my view section 28(1) places an absolute duty on the actor to deal with degradation or pollution, whether it is preventing, ending or minimising harm that has occurred. Reasonableness in this sense only refers to the type of measures employed to prevent or discontinue the harm. In other words, the farmer that leases land with GM crops is held strictly liable for any damage, but will only be required to employ measures that are practically and realistically possible to prevent or end the damage. Should the person fail to take care of the damage, clean-up costs can be recouped from this person. In this instance, I agree with Soltau that

....in an action to recover costs incurred the authorities need not aver nor prove fault. In response, defendants may plead that they undertook reasonable measures as mandated by section 28(1) and are therefore not liable for clean-up costs or other costs incurred by the authorities. ${ }^{83}$

In the Genkor case the court went a step further and stated that in some instances sections 28(1) and (2) may even exclude the element of unlawfulness and impose absolute liability. ${ }^{84}$

Subsection 11 provides that

...if more than one person is liable under subsection (8), the liability must be apportioned among the persons concerned according to the degree to which each was responsible for the harm to the environment resulting from their respective failures to take the measures required under subsections (1) and (4).

Apportionment takes place according to the degree to which each was responsible for the harm to the environment resulting from their failures to take the required measures set out in section 28 . Kidd points out that the difficulty with this provision lies in its peremptory nature. ${ }^{85}$ Joint and several liability allows one to claim against one actor and leave it to him or her to recover the

83 Id at 48-49.

$84 \mathrm{~N} 75$ above at 25.

85 Kidd "Environmental Damage in South Africa" (unpublished - on file with the author). 
costs from the rest. Under section 28 the state must apportion liability amongst all liable actors. Kidd argues that

...it would be foolish for the competent authority to spend money on remediating pollution if it were apparent that the party primarily responsible for the pollution is unable to pay its share of the costs. It would also not be wise of the competent authority to take remediating steps in a case where the various parties potentially liable under s 28(8) were not all known.

Whilst the environmental framework regulation and in particular NEMA creates a liability regime for addressing environmental damage, certain issues remain open, such as for example the matter of financial security referred to above.

\section{The National Environmental Management Biodiversity Act}

Section 78(1) of the Biodiversity Act provides that in instances where the Minister of Environmental Affairs and Tourism has reason to believe that the release of a GMO could pose a threat to the environment or to an indigenous species, no permit for such release should be issued in terms of the GMO Act until an EIA has been conducted. The Minister needs to convey this belief to the relevant authority issuing permits under the GMO Act before the application for a permit is decided. The Act does not set out the circumstances under which the Minister may intervene and it is inconceivable that notification of every application is required. It is therefore not clear what would in fact motivate the Minister to believe that the release of a GMO poses a threat.

To address this matter the GMO Act should provide for a requirement of notification under specified circumstances to the Minister. In order to give effect to this, the GMO Act must be amended to include such a notification requirement, together with the criteria that will determine when notification would be required. 


\section{Conclusion}

Technological advancement can undoubtedly benefit society as a whole but can also produce harmful results. The law plays an important role in ensuring that we manage and mitigate risk and remedy harm when it occurs. The law should thus balance this responsibility with the potential benefits that can be derived from technology and specifically biotechnology.

South Africa does not as yet have a satisfactory legal regime that provides for risk management and liability in the context of GMOs. The existing legal regime is fragmented, confusing, and in some respects deficient. The primary law regulating GMOs, the GMO Act, does not provide adequate tools for managing the risks associated with GMOs and deals with liability in a cursory manner. The Amendment Bill attempts to address some of these deficiencies and has broadened the scope of liability for environmental damage. It does not, however provide for a holistic liability regime that details elements such as the standard of liability and redress.

While NEMA's future EIA framework does appear to cover GMOs, it does so in a manner that is perplexing and that will not lead to comprehensive risk management. With regard to liability, NEMA's provisions are relatively broad in scope and cover some of the more important aspects of a liability regime. NEMA was not, however, specifically drafted to cover damage resulting from GMOs or GMO related activities. As a result, it does not take into account the possible breath of claims that may arise and the resultant costs associated with clean up and restoration. The scale of the costs necessitates provision for either a financial provision mechanism or mandatory insurance. This is currently lacking and should ideally be provided for in the GMO Act. Until the country adopts a comprehensive regulatory scheme on liability for GMO related damage, plaintiffs may find it challenging to seek redress in the courts. 


\section{Bibliography}

Abramson and Carrato 2001 Va Env'l L J 241-261

Abramson S and Carrato T "Crop Biotechnology: The Case For Product

Stewardship" 2001 (20) Virginia Environmental Law Journal 241-261

Barron 2003 SAJELP 93-110

Barron N "A Case of Throwing Caution to the Wind: a Critical Analysis of the EIA Provisions Contained in the Genetically Modified Organisms Act of South Africa" 2003 (10) SAJELP 93-110

Glazewski Environmental Law 242

Glazewski J Environmental Law in South Africa $2^{\text {nd }}$ ed (Lexisnexis Butterworths Durban 2005)

Graziano 1996 CJIELP 179-202

Graziano K "Biosafety Protocol: Recommendations to Ensure the Safety of the Environment" 1996 (36) CJIELP 179-202

Guruswamy 2002 Ind J of Global Legal Stud 461-479

Guruswamy L "Sustainable Agriculture: Do GMOs Imperil Biosafety?" 2002 (9) Ind J of Global Legal Stud 461- 479

Kidd "Environmental Damage in South Africa" (unpublished)

Kidd M "Some Thoughts on Statutory Directives Addressing Environmental Damage in South Africa" (unpublished)

Kirkland et al Risk Management 156-158

Kirkland LH et al "Risk Management" in Thompson D (ed) Tools for Environmental Management (New Society Publishers Gabriola Island 2002)156-158 
Repp 2000 Idaho LR 585-591

Repp R "Biotech Pollution: assessing Liability for Genetically Modified Crop production and Genetic Drift" 2000 (36) Idaho LR 585-591

Mellon Biotechnology and the Environment 8

Mellon M Biotechnology and the Environment: A Primer on the

Environmental Implications of Genetic Engineering (National Wildlife

Federation Washington DC 1988)

Ross and Thompson Environmental Impact Assessment 231

Ross W and Thompson D "Environmental Impact Assessment" in

Thompson D (ed) Tools for Environmental Management (New Society

Publishers Gabriola Island 2002) 231

Soltau 1999 SAJELP 33-41

Soltau F "The National Environmental Management Act and Liability for

Environmental Damage" 1999 (6) SAJELP 33-41

Szecsy A 1997 Dick J Envtl L \& Pol'y 177-192

Szecsy A "From the Test Tube to the Dinner Table in Record Time:

Liberalizing Effects on Domestic and International Regulatory Frameworks

for Controlled Environmental Introduction of Genetically Engineered

Agricultural Organisms" 1997 (2) Dick J Envtl L \& Pol'y 177-192

Thompson Genes for Africa

Thompson J Genes for Africa, Genetically Modified Crops in the

Developing World (UCT Press Cape Town 2002)

Webster's College Dictionary

Webster's College Dictionary (Random House Reference 1999) 


\section{Register of legislation}

Agricultural Pests Act 36 of 1983

Constitution of the Republic of South Africa Act 1996

Environment Conservation Act 73 of 1989

Environmental Management: Biodiversity Act 10 of 2004

Fertilisers, Farm Feeds, Agricultural and Stock Remedies Act 36 of 1947

Foodstuffs, Cosmetics and Disinfectants Act 52 of 1972

Genetically Modified Organisms Act 15 of 1997

Genetically Modified Organisms Amendment Bill R 2166 of Government

Gazette 26848 dated 8 October 2004

GN 1047 Government Gazette 26422 dated 11 June 2004

GN 1046 in Government Gazette 26422 dated 11 June 2004

GN 12 in Government Gazette 27163 dated 14 January 2005

GN 1576 Government Gazette 27913 dated 26 August 2005

GN 1591 Government Gazette 27936 dated 26 August 2005

Reg 1182 in Government Gazette 18621 dated 5 September 1997

Reg 1420 in Government Gazette 20463 dated 26 November 1999

Reg 52(2)(d) Government Gazette 26275 of 23 April 2004

Reg 53 Government Gazette 26275 of 23 April 2004

Mineral and Petroleum Resources Development Act 28 of 2002

National Environmental Management Act 107 of 1998

National Environmental Management Amendment Act 8 of 2004

\section{Register of cases}

Chief Pule Shadrack VII Bareki NO v Gencor Limited and others (TPD) Case No 19895/2003 (unreported)

Hichange Investments (Pty) Ltd v Cape Produce Company (Pty) Ltd t/a Pelts Products and others 2004 (2) SA 393 ECD 


\section{Treaties and other international sources}

Basel Protocol on Liability and Compensation to the Basel Convention on the Control of Transboundary Movements of Hazardous Wastes and their Disposal 1991

Convention on Civil Liability for Damage Resulting from Activities Dangerous for the Environment 1993 (Lugano Convention)

Convention on Environmental Impact Assessment 1997 (Espoo Convention) Decision BS-1/8 dated February 2004 to establish an Open-ended Ad Hoc Working Group of Legal and Technical Experts on Liability and Redress

EC Directive on Environmental Liability with Regard to the Prevention and Remedying of Environmental Damage Directive 2004/35/CE 21 April 2004

\section{Register of Internet resources}

Biowatch http://www.biowatch.org.za/docs/booklets/gebk4.pdf 15 Jun Biowatch South African People and Environment in the Global Market [Found on Internet] http://www.biowatch.org.za/docs/booklets/gebk4.pdf [Date of use 15 June 2005]

Cartagena Protocol http://www.biodiv.org/biosafe/protocol.asp 15 Jun Cartagena Protocol on Biosafety to the Convention on Biodiversity 2000, signed June 2003, acceded August 2003 [Found on Internet] http://www.biodiv.org/biosafe/protocol.asp [Date of use 15 June 2005] 